\title{
SETTING OF PLANTATION LAND AREA LIMITATION BASED ON SOCIAL FUNCTION PRINCIPLES OF LAND CULTIVATION RIGHTS TO REALIZE SOCIAL WELFARE-PROMOTING PLANTATION ${ }^{\Omega}$
}

\author{
Lego Karjoko, I Gusti Ayu Ketut Rachmi Handayani and Adi Sulistiyono \\ Faculty of Law, Universitas Sebelas Maret Surakarta \\ E-mail: kkarjoko63@yahoo.co.id
}

\begin{abstract}
The existence of large plantations in Indonesia has proven the failure of individualism value to uphold agrarian justice. This study aims to examine regulations regarding to the land ownership which contradicts with social function principles of Land Cultivation Rights (LCR) and provide recommendation for setting the land ownership which can realize land utilization for plantation ideally. This study employs normative legal research method by statute and conceptual approach. The legal materials were analyzed by inductive, deductive and interpretative syllogism. The results of this research are as follows. First, regulations on Site Permit, Plantation Operation Permit and Release of Forest Area for Plantation based on utilitarian justice and concentrative land ownership are not in accordance with social function principles of Land Cultivation Rights (LCR). Second, the setting of maximum ownership for plantation companies should be based on their type of plants and given fully assets that enable the plantation companies to use the land optimally.
\end{abstract}

Keywords: land cultivation rights, cultivation land area, people's welfare

\begin{abstract}
Abstrak
Keberadaan perkebunan besar di Indonesia telah membuktikan kegagalan nilai individualisme untuk mewujudkan keadilan agraria. Penelitian ini bertujuan untuk menguadit peraturan mengenai luas penguasaaan tanah perkebunan yang bertentangan dengan asas fungsi sosial hak guna usaha (HGU), dan memberikan preskripsi pengaturan luas penguasaan tanah perkebunan yang dapat mewujudkan pemanfaatan tanah untuk usaha perkebunan secara optimal. Penelitian ini menggunakan metode penelitian hukum normatif, dengan pendekatan statute approach, dan conceptual approach. Bahan hukum dianalisis dengan silogisme induksi, deduksi dan interpretasi. Hasil penelitian adalah pertama, peraturan kebijakan tentang Izin Lokasi, Perizinan Usaha Perkebunan, dan Pelepasan Kawasan Hutan, yang berorientasi pada keadilan utilitarianisme dan penguasaan tanah secara konsentratif, tidak koheren dengan asas fungsi sosial HGU. Kedua, pengaturan luas maksimum penguasaan tanah bagi perusahaan perkebunan seharusnya berdasarkan jenis tanaman dan modal yang ditempatkan dan disetor penuh sehingga pengusaha perkebunan dapat memanfaatkan tanah secara optimal.
\end{abstract}

Kata kunci : asas fungsi sosial HGU, luas tanah perkebunan, kesejahteraan rakyat

Introduction

Under Pancasila and 1945 Constitution Ar-

ticle 33 Paragraph (3), Law Number 5 Year 1960 on Agrarian Basic Regulations (UUPA) synchronizes individual and collective values which manifest social function principles of Land Cultivation Rights. In doing so, there shall be a regulation which governs the limitation of the ownership of plantation LCR. Other than to optimize plantation operation, the setting of LCR land area is needed to realize social welfare, one of its indicators is equal distribution of natural resources for the benefit of the people. ${ }^{1}$

$\Omega$ This article is part of research from Penelitian Hibah Disertasi and Doktor Baru UNS entitled "Pembadanan Asas Fungsi Sosial Hak Guna Usaha Dalam Pengaturan Konsesi Perkebunan Yang Mensejahterakan Rakyat", funded by DIPA PNBP UNS Contract Number: 632/UN27. 21/LT/2016 On April, 262016.

1 Yance Arizona, "Perkembangan Konstitusionalitas Penguasaan Negara Atas Sumber Daya Alam dalam Putusan Mahkamah Konstitusi”, Jurnal Konstitusi, Vol. 8 No. 3, June 2011, Jakarta: Mahkamah Konstitusi RI, page 301. 
Practically, from the New Order to reformation era, plantation law is more concerned with individual value rather than supporting on land ownership concentration for plantation companies which expected to create prosperity by providing job vacancy with appropriate salary of each district or city. Furthermore, land concentration is needed to ensure food security and sovereignty. ${ }^{2}$ Individual value as land political basis with a large scale of expropriation policy produces inequality of land ownership, which is the root conflict of plantations. ${ }^{3}$

Agricultural Census shows that there is no change in the structure of land ownership for over 40 years from 1963-2003. This ratios of land ownership from 1963 to 2003, either for landholders or the entire household farmers consistently show numbers above 0,5 with the tendency of getting higher over time. It shows that at those period of time, the inequality of land ownership is getting worse. The number of landlessness from time to time also increases. The inequality of land ownership and landlessness is the root conflict of plantation. ${ }^{4}$ For instance, PT. Ubertraco/Nafasindo the LCR owner of Palm Plantation with the people of Aceh Singkil District, if we compare the area of Singkil Aceh District which is $21.870 \mathrm{Ha}$ with the LCR area of PT. Ubertraco/Nafasindo which $13.978 \mathrm{Ha}$, it means that $\pm 60 \%$ area of Aceh Singkil District is LCR PT. Ubertraco/Nafasindo area. ${ }^{5}$ Therefore, conflicts of plantations occurs since the social function principles of Land Cul-

2 Nurhasan Ismail, "Arah Politik Hukum Pertanahan dan Perlindungan Kepemilikan Tanah Masyarakat”, Jurnal Rechtsvinding, Vol. 1 No. 1, January - April 2012, Jakarta: Badan Pembinaan Hukum Nasional, page 40-41.

3 Noer Fauzi Rachman, "Rantai Perjelas Konflik-Konflik Agraria Yang Kronis, Sistemik, dan Meluas Di Indonesia", Bhumi, No. 37 Tahun 12, April 2013, Yogyakarta: PPPM Sekolah Tinggi Pertanahan Nasional, page 4.

4 Dianto Bachriadi dan Gunawan Wiradi, 2011, Enam Dekade Ketimpangan: Masalah Penguasaan Tanah Di Indonesia, Bandung: Agrarian Resource entre, Bina Desa, Konsorsium Pembaruan Agraria, page 44.

5 Rifai affandi, Ilyas Ismail, Suhaimi, "Penyelesaian Sengketa Penguasaaan Tanah Hak Guna Usaha (HGU) Perkebunan Kelapa Sawit Antara PT. Ubertraco/Nafasindo Dengan Masyarakat (Suatu Penelitian di Kabupaten Aceh Singkil)", Jurnal Ilmu Hukum, Vol. 2 No. 2, November 2013, Banda Aceh: Postgraduate Syiah Kuala University, page 81. tivation Rights is not used as guidance in making regulations for plantation ownership.

\section{Problems}

Problem for this study is based on theoretical assumption that social function principle of LCR as a principle to formulate regulation of realistic plantation ownership can realize land utilization for plantation business optimally. Accordingly, the formulation of the problems are: first, are regulations on plantation ownership coherent with social function principles of LCR; and second, how should the regulation of plantation ownership be implemented to realize the land utilization for plantation business optimally?

\section{Research Method}

This is a normative legal research method which aims to figure out and provide recommendation of plantation ownership regulation which is coherent with social function principle of LCR. This research employed statute approach and conceptual approach. Statute approach is used to figure out ratio legis and ontological basis of the issue of regulations about Site Permit, Plantation Operation Permit and Release of Forest Area for Plantation. Thus, it can be identified whether there is a presence or an absence of philosophical content conflict to the regulation with social function principle of Land Cultivation Rights. The approach is aimed to find out the legal definition of social function principle of Land Cultivation Rights.

Legal materials were analyzed by inductive, deductive and interpretative syllogism. Inductive syllogism is used to find the concept and indicator of social function of Land Cultivation Rights from Agrarian Basic Regulations (UUPA). Furthermore, deductive syllogism is applied in which the mayor premises are Pancasila, law of nature, idealism, progressive law, theory of justice, rights of controlling state, and social function principle of Land Cultivation Right. Meanwhile the minor premises are regulations of cultivation land area ownership in (1) Agrarian and Spatial Planning Ministerial Regulation/the Head of National Land Agency Number 
5 Year 2015 on Site Permit, (2) Minister of Agriculture Regulation Number 98/Permentan/OT. $140 / 9 / 2013$ on Guidelines of Plantation Operation Permit, (3) Forestry Ministerial Regulation Number P.33/Menhut- II/2010 on The Procedure of Release of Convertible Production Forest Area.

\section{Discussion}

\section{Regulation of Cultivation Land Area Owner- ship Oriented to Utilitarianism Justice}

Social function of land ownership to count unlimited property right was introduced by Henri Hayem in 1910 and several years later it was disseminated by Leon Duguit. ${ }^{6}$ Duguit used social dynamics theory by Auguste Comte and social solidarity theory by Emile Durkheim to propose the theory of social function of property: "Someone cannot do what he wants with his property. He is obliged to make it productive. When he does not act in a manner consistent with his obligations, the state should intervene to encourage or to punish him". ${ }^{7}$

In 1970s, the New Jersey Supreme Court famously wrote in a landmark case involving the rights of migrant workers while on the land of their farmer-employer: "Property rights serve human values. They are recognized to that end, and are limited by it. Title to real property can not include dominion over the destiny of persons. Indeed the needs of the occupants [of another's property] may be so imperative and their strength so weak, that the law will deny the occupants the power to contract away what is deemed essential to their health, welfare, or dignity. ${ }^{8}$

$6 \quad$ M. C. Mirow, "The Social-Obligation Norm of Property: Duguit, Hayem, and Others", Florida Journal of International Law, Vol. 22, Edition November 2010, Florida: Law Florida International University, page 195, available on website http://ssrn.com/abstract=1662226, accessed on November $23^{\text {th }}$, 2012.

7 Sheila R. Foster \& Daniel Bonilla, "Symposium The Social Function of Property: A Comparative Perspective", For-dham Law Review Vol. 80 2011, New York: Fordham Uni-versity School of Law, pages 1004-1005, available on website http://ir.lawnet.fordham.edu/fr/vol80, accessed on November $19^{\text {th }} 2012$.

8 Colin Crawford, "The Social Function of Property and the Human Capacity to Flourish", Fordham Law Review Vol. 80, 2011, New York: Fordham University School of Law, page 1090, available on website http://ir.lawnet.
In the beginning of the $21^{\text {th }}$ century, Gregory S. Alexander developed social-obligation theory of property as an alternative of law and economics theories about property that dominated the thought of American contemporary jurists. At the normative level, social-obligation norm is more superior morally since it promotes the development of human flourishing, that is enabling individuals to live properly as dignified human. Drawing on Amartya Sen and Martha Nussbaum's capabilities approach, the socialobligation theory holds that all individuals have an obligation to others in their respective communities to promote the capabilities that are essential to human flourishing. For property owners, this has important consequences. If we accept the existence of an obligation to foster the capabilities necessary for human flourishing, and if we understand that obligation as extending to an obligation to share property, at least in surplus resources, then it follows that to enhance the abilities of others to flourish, in the predictable absence of adequate voluntary transfers, the state should be empowered and may even be obligated to compel the wealthy to share their surplus with the poor so that the latter can develop the necessary capabilities. None of this is meant to suggest that the state's power, even as it touches on the facilitation of the capabilities we are discussing, is unbounded. But the limits to the state's proper domain are supplied by the same principles that justify its action: the demands generated by the capabilities that facilitate human flourishingfreedom, practical rationality, and sociality, among others. ${ }^{9}$

Based on the second principle of Pancasila, 'Just and civilized humanity', social function principle of land ownership is directed to human who carry out humanitarian activities and make their value as human (monopluralis) optimally. That is the realization of "human being". Based on Article 6 of Basic Agrarian Law

fordham.edu/fr/vol80/iss $3 / 5$, accessed on November $18^{\text {th }} 2012$.

9 Gregory S. Alexander, "The Social Obligation Norm in American Property Law", Cornell Law Review Vol. 94 No. 745, 2009, Cornell Law School, pages 745-746. 
Subjects and its explanation, there are three indicators of social function principle of Land Cultivation Rights: first, the conformity of land utilization with circumstance and characteristic or purpose of Land Cultivation Rights; second, the intensity of land utilization for plantation operation; third, the orientation of land utilization to attain the stability of interest fulfillment between Land Cultivation Rights holders, society, and environmental conservation (the stability of production and conservation).

The maximum ownership of plantation land area for one company or a group of plantation companies is governed differently by three policy regulations: first, Ministry of Agrarian and Spatial Planning Regulation/ the Head of National Land Agency Number 5 Year 2015 on Site Permit:

a. for cane commodity is 60.000 ha in one province or 150.000 ha for entire Indonesia;

b. for other food commodities are 20.000 ha in one province or 100.000 ha for entire Indonesia;

c. for Papua and West Papua Provinces: 120.000 ha for cane commodity and 40.000 ha for other food commodities;

d. unlimited ownership of plantation land area for State-Owned Enterprises (BUMN) in form of Public Companies (Perum) and Regional Owned Enterprises (BUMD), Enterprises which are either entirely or partially owned by government both central and regional, Enterprises that are either entirely or partially owned by society in order to go public.

Second, Ministry of Agriculture Regulation Number $98 /$ Permentan/OT.140/9/2013 on Guidelines of Plantation Operation Permit:

a. The holders of B-Plantation Operation Permit (IUP-B) can own the land up to 102.000 ha, with stipulation: Coconut 40.000 ha; Rubber 20.000 ha; Coffee 10.000 ha; Cocoa 10.000 ha; Cashew 10.000 ha; Pepper 1.000 ha; Cotton 1.000 ha; Clove 10.000 ha.

b. The holders of Plantation Operation Permit (IUP) can possess the land up to 270.000 ha, with stipulation: Palm Oil 100.000 ha; Tea 20.000 ha; Cane 150.000 ha. c. The holders of IUP-B or IUP in Papua and West Papua Provinces can be granted the land which is twice wider than the most extensive limit in letter $a$ and $b$.

d. Unlimited ownership of cultivation land area for State-Owned Enterprises, Regional Owned Enterprises, Cooperatives, and Cultivation Companies with go public status and their shares are mostly owned by society.

Third, Ministry of Forestry Regulation Number P.33/Menhut-II/2010 on The Procedure of Release of Convertible Production Forest Area: the area of released convertible production forest for one company or a group of cultivation companies is as follows:

a. Non-Cane Commodity: 100.000 hectare, particularly for Papua Province and West Papua Province: 200.000 hectare.

b. Cane Commodity: 150.000 hectare, particularly for Papua Province and West Papua Province 300.000 hectare.

Those three policies which authorize plantation business dominate the land in wide scale. It potentially caused unfulfillment for social function principle of LCR such as intensity of utilization of land for plantation. LCR ownership does not have adequate capability to manage the land efficiently and keep the quality of the land; therefore, the land is being abandoned. Plantation Companies potentially abandon the land because of underutilization of HGU land for plantation business. "The challenge is not only to meet the world population's needs for food, shelter and quality of life, but also to ensure that future generations can have their needs met". Any response to this must focus on long-term as well as short-term issues. Sustainability is no longer an option, it should be an essential. The world needs to develop more intense and sustainable use of the land. Wasting space by abusing the land should be seen as a crime. According to the head of National Land Agency, Joyo Winoto, the underutilized plantation land area in Indonesia around 7,1 million ha in 2007 with the assumption the plan- 
tation land is being utilized in avarage level, it will loss 78,2 trillion per year. ${ }^{10}$

The three policies that authorize plantation business to dominate the land in conservatively create the dominance of plantation land ownership that will impact to prosperity. According to Joyo Winoto, 0, 2 \% Indonesian dominates around $56 \%$ asset of land, in the form of property, land, and plantation. The dominance of land ownership and land underutilization will threat the resident around the area to utilize the underutilization land and reclaim the plantation land. The conflict between plantation land owner and farmer raise violence which results in creating victims.

On the one side, the policies are coherent with efficiency with justice principle in conducting national economic referring to 1945 Constitutional, Article 33 paragraph (4). The efficiency with justice is market economic system oriented to individualism. The justice that refers to fair efficiency principle relates to capitalism where the land can be dominated and utilized by certain people who can maximize the land such as big plantation company. By focusing land ownership to Plantation Company, it is expected to gain the prosperity equality by the availability of job vacancy with appropriate salary of each districts or city. ${ }^{11}$ On the other hand, one of the policies actually threats the accumulation and domination of plantation land area ownership in big scale which is not in accordance with 1945 Constitution, Article 33 paragraph (3), giving mandate to the country to create prosperity by upholding the equality of land utilization for people. ${ }^{12}$

According to Lon Fuller ${ }^{13}$ there are two ideologies which contradict to 1945 Constitution

10 Joyo Winoto, Reforma Agraria: Mandat Politik, Konstitusi dan Hukum dalam Rangka Mewujudkan Tanah untuk Keadilan dan Kesejahteraan Rakyat", Makalah. Proposal delivered on Public Lecture in UGM, Yogyakarta, November $22^{\text {th }} 2007$, page 5 .

11 Nurhasan Ismail, op.cit., page 40.

12 Yance Arizona, loc.cit.

13 David Luban, "The Rule of Law and Human Dignity: Reexamining Fuller's Canons", Georgetown Public Law and Legal Theory Research Paper No. 10-29 Edition May 2010, page 2, available on website http://scholarship. law.georgetown.edu/facpub/369/, accessed on January $5^{\text {th }} 2017$.
Article 33 which cause the failure of plantation justice in optimizing plantation business. Although the policy oriented to utilitarianism justice theory that refers to 1945 Constitution, Article 33 paragraph (4), the policy is not valid and have basic legality, it is contradictory to the value of the second principle of Pancasila, "justice and civilized humanity" with the value of land ownership addressed to human as human being.

Based on Hegel's perspective ${ }^{14}$ the policy that allows the plantation company to dominate plantation land in big scale is contradictory to 1945 Constitution, Article 33 paragraph (3) giving mandate to the country to create prosperity by upholding the equality of land utilization for people. ${ }^{15}$ According to Thomas Aquinas, the policy that oriented to land conservative domination is not coherent because it neglects and discriminates people. Hence, the policy is illegal due to its contradictory to the nature of law and God. ${ }^{16}$

Three policies oriented to conservative land ownership are not justified from progresssive law which believes in ideology of justice and people's prosperity. ${ }^{17}$ By this ideology, the dedication of Ministry of agrarian and head of National Land Agency (BPN) and ministry of forestry should recover the agrarian injustice or remove the dominance of land ownership. The policy shows the dedication of ministry of agrarian and head of National Land Agency (BPN) and ministry of forestry that supports the dominance of conservative land ownership.

\section{The Limitation of Plantation Land Area based on Social Function Principle of Land Cultiva- tion Right}

The limitation of plantation land area should be regulated to optimize the utilization

\footnotetext{
14 Suyahmo, “Filsafat Dialektika Hegel: Relevansinya Dengan Pembukaan Undang-Undang Dasar 1945”, Humaniora, Vol. 19 No. 2, 2007, Yogyakarta: Faculty of Humanities Universitas Gadjah Mada, page 147.

15 Yance Arizona, loc.cit.

16 Bernard L. Tanya, Yoan N. Simanjuntak, Markus Y. Hage, 2010, Teori Hukum Strategi Tertib Manusia Lintas Ruang dan Generasi, Yogyakarta: Genta Publishing, page 59.

17 Ibid., page 212 .
} 
of land for plantation business. Nowadays, in Europe, the restriction of plantation land is regulated by the owner including the business, the setting of the land and speculation space. ${ }^{18}$

Article 14 of Law number 39 year 2014 on Plantation grants authority to government to limit the maximum and minimum use of plantation land area for business that consider the plant species and the asset. To realize the indicator of the land use intensity for plantation busines, there should be a regulation in terms of Site Permit, Plantation Operation Permit and Release of Forest Area for Plantation related to the maximum size of land area for Plantation Companies based on their type of plants and assets which is fully granted to the owner of LCR. Therefore, they can use it for their plantation business at most and it will be really beneficial for the prosperity of the people and the owner's own happiness, also providing beneficial to the surrounding and the country. The maximum limitation setting of the land authorization aimed to fix the agricultural inequity or reducen the land authorization imbalance that is according to the purpose of Article 33 paragraph (3) 1945 Constituions in order to actualize the equality of land benefit for people.

\section{Conclusion}

The policy regulations of Site Permit, Plantation Operation Permit, and The Release of Forest Area allow the agricultural company to dominate the land unlimited which is not coherent with the social funcion principle of Land Cultivation Right (LCR) which is the intensity of the land use for the plantation bussiness. According to social funcion principle of LCR, the maximum limitation setting of land authorization must be based on the type of the plant and the real and fully deposited aset so that the plantation company can optimally use the land.

\section{Suggestion}

People's Consultative Assembly of Indonesia shall arrange the fifth amandment of Article

18 Peter Sparkes, 2007, European Land Law, Oregon: Hart Publishing, page 75.
33 paragraph (4) 1945 Constitution in which the "efficiency with justice principle" in the enforcement of national economy is amended to "social fair principle". The government should revise the regulation of ministry of agraria and spatial/ The Head of National Land Agency Number 5 Year 2015 on Site Permit, The Regulation of Minister of Agriculture Number 98/Per mentan/OT.140/9/2013 on The Guide of Plantation Operation Permit, and The Regulation of Ministry of Forestry Number P.33/Menhut-II/ 2010 on the system of convertible productive forest release which allows the consentrative land authorization. The limitation setting to the plantation company should be based on the types of the plants and the real or fully deposited aset.

\section{References}

Affandi, Rifai. Ilyas Ismail. Suhaimi. "Penyelesaian Sengketa Penguasaaan Tanah Hak Guna Usaha (HGU) Perkebunan Kelapa Sawit Antara PT. Ubertraco/Nafasindo Dengan Masyarakat (Suatu Penelitian di Kabupaten Aceh Singkil)". Jurnal Ilmu Hu-kum. Vol. 2 No. 2. November 2013. Banda Aceh: Post Graduate of Universitas Syiah Kuala;

Alexander, Gregory S.. "The Social Obligation Norm in American Property Law". Cornell Law Review. Vol. 94 No. 745. 2009. New York: Cornell Law School;

Arizona, Yance. "Perkembangan Konstitusionalitas Penguasaan Negara Atas Sumber Daya Alam dalam Putusan Mahkamah Konstitusi". Jurnal Konstitusi. Vol. 8 No. 3, June 2011. Jakarta: Constitutional Court of Indonesia;

Bachriadi, Dianto dan Wiradi, Gunawan. 2011. Enam Dekade Ketimpangan: Masalah Penguasaan Tanah Di Indonesia. Bandung: Agrarian Resource Centre, Bina Desa, Consortium of Agricultural Reformation;

Crawford, Colin. "The Social Function of Property and the Human Capacity to Flourish". Fordham Law Review. Vol. 80. 2011. New York: Fordham University School of Law. Available on http://ir.law net.fordham.edu/fr/vol80/iss3/5. Accessed on November $18^{\text {th }} 2012$;

Dale, Peter. "The Importance of Land Administration in The Development of Land Mar- 
kets Global Perspective". Available on http:/ / www.landentwicklung-muenchen. de/aktuelle_aufsaetze_extern/seminar_0 4.pdf. Accessed on December $5^{\text {th }} 2014$;

Rachman, Noer Fauzi. "Rantai Perjelas KonflikKonflik Agraria Yang Kronis, Sistemik, dan Meluas Di Indonesia". Bhumi. No. 37 year 12. April 2013. Yogyakarta: PPPM of National Land College of Indonesia;

Foster, Sheila R. and Bonilla, Daniel. "Symposium The Social Function of Property: A Comparative Perspective". Fordham Law Review. Vol. 80. 2011. New York: Fordham University School of Law. Available on http://ir.lawnet.fordham.edu/fr/vol 80. Accessed on November 19 $9^{\text {th }}$ 2012;

Iskandar. "Aktualisasi Prinsip Hukum Pelestarian Fungsi Lingkungan Hidup dalam Kebijakan Perubahan Peruntukan, Fungsi, dan Penggunaan Kawasan Hutan". Jurnal Dinamika Hukum. Vol. 11 No. 3. 2011. Purwokerto: Faculty of Law, Universitas Jenderal Soedirman;

Ismail, Nurhasan. "Arah Politik Hukum Pertanahan dan Perlindungan Kepemilikan Tanah Masyarakat". Jurnal Rechtsvinding. Vol.1 No. 1. January-April 2012. Jakarta: The National Law Development of Indonesia;

Luban, David. "The Rule of Law and Human Dignity: Reexamining Fuller's Canons", Georgetown Public Law and Legal Theory Research Paper. No. 10-29. May 2010.
Available on http://scholarship.law.geor getown.edu/facpub/369/. Accessed on January $5^{\text {th }} 2017$;

Mirow, M. C.. "The Social-Obligation Norm of Property: Duguit, Hayem, and Others". Florida Journal of International Law. Vol. 22 Edition November 2010. Florida: Law Florida International University. Available on http://ssrn.com/abstract=1662226. Accessed on November $23^{\text {th }}$ 2012;

Mubyarto, "Paradigma Kesejahteraan Rakyat dalam Ekonomi Pancasila". Jurnal Ekonomi Rakyat. Article year II No. 4. July 2003. Jakarta: Yayasan Agro Ekonomika (YAE). Published in: http:/ / www.ekonomirakyat. org, Accessed on January $11^{\text {th }} 2016$;

Sparkes, Peter. 2007. European Land Law. Oregon : Hart Publishing;

Suyahmo. "Filsafat Dialektika Hegel: Relevansinya Dengan Pembukaan Undang-Undang Dasar 1945”. Humaniora. Vol. 19 No. 2. 2007. Yogyakarta: Faculties of Humanities Universitas Gadjah Mada;

Tanya, Bernard L. Yoan N Simanjuntak and Markus Y Hage. 2010. Teori Hukum Strategi Tertib Manusia Lintas Ruang dan Generasi. Yogyakarta: Genta Publishing;

Winoto, Joyo. "Reforma Agraria: Mandat Politik, Konstitusi dan Hukum dalam Rangka Mewujudkan Tanah untuk Keadilan dan Kesejahteraan Rakyat". Paper. Delivered in General Lecture in Universitas Gadjah Mada. Yogyakarta, November $22^{\text {th }} 2007$. 